\title{
Editors' note: On Community, Collaboration, and Difference
}

\author{
Harmony Bench, The Ohio State University
}

Simon Ellis, University of Roehampton

\begin{abstract}
Strangely, the foreigner lives within us: he is the hidden face of our identity, the space that wrecks our abode, the time in which understanding and affinity founder. By recognizing him within ourselves, we are spared detesting him in himself. A symptom that precisely turns 'we' into a problem, perhaps makes it impossible, the foreigner comes in when the consciousness of my difference arises, and he disappears when we all acknowledge ourselves as foreigners, unamenable to bonds and communities.
\end{abstract}

- Julia Kristeva ${ }^{1}$

When we put together the call for papers for this journal issue, inspired by prompts from Marisa Zanotti, we were thinking simply of what goes on beyond the frame. As Charles Atlas remarked in an interview, "I wanted to explore things that related to my life; less about the studio, more about what's outside the studio." ${ }^{2}$ We were thinking of such questions as: What are the networks and support structures that enable each of us to do our work? What communities do we draw from creatively and intellectually? Who are audiences and interlocutors for our work? We were not explicitly thinking of global politics, and yet, a theme such as community invites us to reflect more broadly on the boundaries of the communities to which we belong or with which we identify, the stakes inherent in those identifications, and the mutual responsibility that attends investments in a community and its identity.

In the past weeks and months leading up to this journal issue, the 'international community' has expressed concern over Greece's financial well-being, Russia's operations in the Ukraine, Ebola outbreaks in West Africa, \#blacklivesmatter protests throughout the United States, the drowning deaths of 900 souls trying to reach Europe from Libya, and thousands dead in Nepal after a devastating earthquake. Each of these scenes of chaos, vulnerability, catastrophe, and pain asks us to consider: what is community, and how far does it extend? What is the 'we' implicit in community as both its promise (premise) and its impossibility? How far can intention toward community reach before fellow-feeling transforms into xenophobia, or before the support we lend 
each other out of care becomes our only means of surviving the logics of neoliberal economies?

Communities are dependent on exclusion. In order to recognize belonging, others must be seen as just that: other. The recognition of (or perhaps desire for) difference-in attitudes, voice, taste, race, gender, class, etc.-carries with it demanding and important ethical concerns for how it is that we-as individuals and in our various communities-make choices, including the choices that are made on our behalf, and those with which we are complicit through ignorance or silence.

So there is, on the one hand, the geo-political realm in which communities, identities/identifications, and ethical responsibilities are negotiated, and on the other, there are intellectual and aesthetic communities that grow within and across geopolitical boundaries, as well as disciplinary boundaries. Not only are aesthetic communities informed by this larger geo-political backdrop, they take shape in relation to its hierarchies, its flows of information and economic resources, and the circulations of ideas and people it affords or curtails. The politics of screendance communities may differ in substance from those of nation-states, but they share the structural problems of access and economics.

Screendance's development as a hybrid discipline-emerging from choreographic, visual, and cinematographic thinking - has long been dependent on films presented as (more or less curated) collections at screendance festivals. These festivals are now fewer in number (particularly in the UK) and many artists are seeking alternative ways of creating shared spaces to present, watch, and talk about their work. At the same time, screendance is taking hold in undergraduate university dance programs around the world. These two developments-alternative or experimental platforms for presenting work, and screendance-specific higher education courses-mark a pivotal moment to explore how the nature of community in our discipline is changing, and how screendance might offer changes in the ways in which humans make, watch, and think together. In an era in which the social fabric has worn thin, artists have worked at building community and incorporated such work into the process of art-making. Collectively, we seek ways to sustain ourselves.

Early in 2015, artists Karen Christopher and Lucy Cash presented a scratch performance of a conversation at the University of Roehampton's Department of Drama, Theatre and Performance Studies. ${ }^{3}$ During the conversation they reflected on how the words 'carrying' and 'caring' are threaded together in the way they describe actions that involve two or more beings who are in relation to each other. It is the nature of this relationship-or these relationships-that is the subject of this volume. How might the screendance community express care? Can we even talk about a singular screendance community? How do screendance practitioners, scholars and students understand and express care that is distinct from other practices? If IJSD is also in part responsible for 
offering support to the development of a disparate community, then what are the dangers implicit in our voice (as a scholarly and artistic journal) of homogenizing the type of thinking, writing, and practices that might accurately represent the work that is currently being done and made? To what extent is IJSD creating-or responding to-a community or communities?

The tangle of exclusion, otherness, self-awareness, and community that Julia Kristeva understands to be embodied within us when we recognize our difference demands that those involved in the collaborative practices of film-making attempt to recognize and understand personal voice, difference, authorship, influence, and power. This is particularly vital in the space and time of choreographic and dance film-making because these processes and their outcomes are watched and felt through the lens and legacy of bodily training, sensitivity, and attention.

This is not to say that screendance is necessarily corporeally-driven, but that the choreographic thinking that underpins screendance practices is extended or tested by our sensitivity to the compressing and expanding spaces between the skins of peoplein-and-out-of-common.

The numerous reoccurrence of performance in image, text, object, and echo-events ... suggest that every rendition of a performance, whatever its form, is itself a different event. ... This is not to deny similarities and continuities between times and between recursive forms-that, for example, a video recording of a performance event may substantively deliver the meaning and affects of the said event to new spectators-but rather it is to assert that the relation of the two events is marked by some evident and unknowable differences. Each event in each differently functioning form is produced in and by the complex intersubjective and inter-sensorial co-minglings of its participant-spectators/readers. Such contexts are not pre-discursive, and whether or not they involve 'solitary reception' (a 'single' body watching a pre-recorded body on a screen for example) they are inherently social: involving numerous subjectivities, numerous active beings in and of numerous times, diverging and converging in the times of the event of reading. ${ }^{4}$

Human beings seek to identify, connect, and converse with others. Not surprisingly, why we work together in screendance and the ways in which we work together are key. These methods are often face-to-face or side-by-side, but increasingly involve various forms of virtual exchange via screens-togetherness at a distance. The experimental nature of these communal exchanges is reflected in the distinct ideas that the authors in this volume test and reveal in their writing and work. It is fitting that in an issue devoted to broad issues of community in screendance, most of the contributionsincluding this editorial-are written by people in conversation or dialogue. Perhaps the 
number of collaborative contributions also reflects complex contemporary economies of production in which our feeling of time is compressed, and we seek the company of others in order to make things seem imaginable or even achievable.

Anthropologist-philosopher Tim Ingold suggests such companionship is best nourished not in face-to-face communication where people "appear to be locked in a contest in which views are no longer shared but batted back and forth," ${ }^{5}$ but side-by-side when we are stimulated and provoked by similarly moving fields of view. Conversely, describing relational movement, Erin Manning stands toe-to-toe with her dancing other in the Argentine tango. ${ }^{6}$ Together they are "looking for the holes" ${ }^{17}$ or intervals that make the dancing possible:

Relational movement means moving the relation. Moving the person will never result in grace, intensity of movement can only be felt when the inbetween - the interval-created by the movement-with takes hold. This interval is ephemeral, impossible to grasp as such, essential to the passage from a step to a graceful movement. ${ }^{8}$

The key for both Ingold and Manning is perhaps not about the nature of the physical orientation between people-either toe-to-toe or side-by-side. Indeed it is not the people who comprise the relationship that are moved, but the relationship or the interval. The interval is adaptive, pliant, and able to express or "propel" ${ }^{9}$ the dance. In order to understand the nature of the spaces between people in communities, and to develop sensitivity to these spaces, it is useful to imagine communal acts as being those that negotiate the intervals between participants, and not the participants themselves. In this situation, a community becomes a series of divergent opportunities-or affordances-for recognizing difference. Such communities in screendance would be recognizable by heterogeneity: alternate and distinctive voices around the world between which the spaces of screens are choreographed, and filled or opened out.

This volume of the International Journal of Screendance is the first themed version since the journal began in 2010. It contains contributions-articles, interviews, reviews and provocations and viewpoints-that reflect the diverse community of screendance practitioners, thinkers, and scholars. Each piece of writing in turn reveals distinct concerns for the subject of community in screendance, with collaborative creation, globality, and audience reception emerging as prominent themes.

Elena Benthaus explores the role of online communities and conversations in her analysis of the 'WOW-affect' amongst spectators of So You Think You Can Dance, and Karen Wood tests the ways in which audiences identify-and behave-as communities in her article, sorting through the role of empathy in viewing and interpreting screendance in "Audience as community: corporeal knowledge and empathetic viewing." Benthaus challenges the concept of kinesthetic empathy, which has fueled many considerations of how audiences interact with and respond to danced movement, 
suggesting that spectacular or virtuosic dancing suspends an audience's ability to respond. One is simply left with 'WOW,' an utterance that evidences affective transmission without necessarily bringing empathy, understanding, or interpretation in its wake. For Wood's focus groups responding to experimental works for screen rather than commercial television, the empathic register is pronounced. It opens a space for the viewers' responses, developed through conversations that take the viewers beyond the moment of visual impact to one of interpretation. In "Being a video-choreographer," Heike Salzer and Ana Baer also consider the relationship between artist and audience, weaving Baer's history of making films and curating the Sans Souci Festival into a larger consideration of the ways in which screens are central to Baer's understanding of choreographic and curatorial practice.

Collaborative approaches to dance-making and dance-filmmaking abound in this issue. Mitchell Rose, Marisa Hayes, and Joséphine Garibaldi and Paul Zmolek specifically reflect on the global reach of collaborative practices in their contributions. In "Global Corporeality: Collaborative Choreography in Digital Space," Garibaldi and Zmolek offer a critical analysis of the ways in which screens, cameras, and freely available software might help shape a transcontinental community of dancers in Latvia and the United States. They speak frankly of the challenges they faced as they composed a multilocational, multi-media performance while straddling continents and languages. In "Crowd-Sourced Filmmaking: Despair is Your Friend," Rose also outlines his experience of making the crowd-sourced film Globe Trot, detailing the labor of composing a film out of footage shot by videographers around the world into a coherent whole. Marisa Hayes also tells of how she coordinated the 'transauthorial exquisite corpse' process of creating a screendance in response to Stravinsky's Le Sacre du Printemps. Built in episodes with contributions from artists with diverse backgrounds and at varying stages in their careers, the resulting films modeled a form of collectivity in the making. Each of these authors approach the question of community through collaboration, finding in collaborative processes both the site of community, and, in some instances, its limit.

David Hinton and Siobhan Davies also contemplate the role of individual agency when constructing a single work from the contributions of many artists. In conversation with Simon Ellis, Hinton and Davies evaluate the process that unfolded around their recent work The Running Tongue, noting the successes of the project as well as the moments where their ideals of community were beyond what was practical or practicable. In conversation with Harmony Bench, Victoria Marks similarly calls out the notion of community as an ideal. As she notes in "Mobilizing Subjectivity," her 'Action Conversations' bring together individuals and groups of people that would not typically be in the same room. Marks asks what can happen when we truly acknowledge each other's differences-what are the ways we can come together, and what is needed to facilitate togetherness within and alongside difference? 
In addition to two reviews-Hetty Blades on The Oxford Handbook of Dance and the Popular Screen edited by Melissa Blanco Borelli, and Rosamaria Kostic Cisneros on Body Knowledge: Performance, Intermediality, and American Entertainment at the Turn of the Twentieth Century by Mary Simonson - this issues contains the provocation In the Forest Between Us by independent artist Lucy Cash. In her writing, Cash recognizes that visiting the "edges of the unfamiliar" in her practice is made possible by various kinds of dialogue.

Such dialogues are at the heart of working together and cooperating in communities. For Brian Eno, our ability to cooperate-to imagine being in at least two worlds at once-is the "whole basis of human specialness."10 Eno suggests further that it is through engaging deeply with culture-most obviously films and novels-that helps us imagine the feelings and experiences of others; they "rehearse us ${ }^{\prime 11}$ for the possibility that the world is not as we experience it.

In seeking out-and building-communities within which to explore, question and practice screendance, we are directly confronted by difference that introduces perceptual and experiential uncertainty. It represents a risk to be with others in order to explore the spaces between us, and to challenge choreographic thinking, but at the same time it nourishes our imaginations and makes surprise possible.

Part of IJSD's remit is to help build a global community of practitioners, scholars and students who-together and apart-are willing to examine the intervals of choreographic and screen-based thinking and doing. Although the practitioners and scholars who responded to our call for proposals are primarily from the US and UK, we recognize the importance of our work-as artists and scholars-to foster globality. Perhaps a small part of this responsibility involves reading, watching, engaging, disputing, and responding to the openly available materials, ideas, and words in this edition of IJSD. In doing so you become part of the nebulous and diverse group of practitioners, academics and students who make claims about-and are claimed byscreendance's histories, cultures, practices, images and texts.

Finally, as part of our desire to make the membership of IJSD's editorial board fluid and representative of the intersecting domains within which we work-both inside and outside of academia-we'd like to welcome two new people to it. Katrina McPherson is an independent artist, renowned screendance maker, and author of Making Video Dance: A step by step guide to creating dance for the screen. She is also one of the people-with original IJSD editors Claudia Kappenberg and Doug Rosenberg-who initially planned and made possible IJSD. Erin Brannigan is a senior lecturer in dance at the University of New South Wales and wrote Dancefilm: Choreography and the Moving Image. Together Erin and Katrina have remarkable experience and understanding of the possibilities and limitations of screendance practice and theory. By encouraging a dynamic editorial board, we hope to ensure that the board-itself a small community of 
artists and academics-is able to reflect and be responsive to changes in the practices, ideas, and work of the broader screendance community. Indeed, this is our hope for IJSD.

We are excited about this issue on community-the second published by The Ohio State University and the first under our stewardship. We hope that you find in its pages an articulation and reflection of our screendance communities. And we would like to take the opportunity to remark upon our own commitment to community.

When Doug Rosenberg and Claudia Kappenberg launched this journal, it was with the clear commitment to raise the visibility and discourse of screendance. We are proud to carry that banner forward. Now, however, we are watching the publication landscape changing around us, and new pay-to-play policies impacting artists' and scholars' ability to publish their work. We are committed to keeping IJSD open-access, and for us this means not only that readers will be able to access the journal's content without hitting a pay wall-it also means that we will not ask authors to pay to have their work reviewed or published. We are committed to serving all of our community-not just those with university affiliations or deep pockets. We are grateful for the opportunity to serve this community, and appreciate everyone's efforts toward support and sustainability.

Harmony Bench and Simon Ellis

30 April 2015

\section{Notes}

${ }^{1}$ Kristeva, 1.

${ }^{2}$ Comer.

3 "Karen Christopher in Conversation with Lucy Cash."

${ }^{4}$ Heathfield, 32 .

${ }^{5}$ Ingold, 106.

${ }^{6}$ See Manning, "The Elasticity of the Almost."

${ }^{7}$ Ibid. 107.

${ }^{8}$ Ibid. 108.

${ }^{9}$ Ibid. 109.

${ }^{10}$ Eno, 357.

${ }^{11}$ Ibid. 357. 


\section{References}

Brannigan, Erin. Dancefilm: Choreography and the Moving Image. New York: Oxford University Press, 2011.

Comer, Stuart. "Life Stages." Frieze 139 (May 2011). Web.

Eno, Brian. A Year with Swollen Appendices, London: Faber and Faber, 1996.

Heathfield, Adrian. "Then Again." Perform, Repeat, Record: Live Art in History. Eds. Amelia Jones \& Adrian Heathfield. London: Intellect Books, 2012. 27-35.

Ingold, Tim. Making, London: Routledge, 2013.

"Karen Christopher in Conversation with Lucy Cash." University of Roehampton, 24 February 2015.

Kristeva, Julia. Strangers to Ourselves. Trans. Leon Roudiez. Lawrence D Kritzman (Ed.), New York: Columbia University Press, 1991.

McPherson, Katrina. Making Video Dance: A Step-by-Step Guide to Creating Dance for the Screen. London: Routledge, 2006.

Manning, Erin. "The Elasticity of the Almost." Planes of Composition. Eds. André Lepecki and Jenn Joy. London: Seagull Books, 2010. 107-21. 